\title{
A monk deploring the assimilation of the Christians to the Hagarenes, attributed to a monk called Apollo
}

Book or Report Section

Accepted Version

Papaconstantinou, A. (2020) A monk deploring the assimilation of the Christians to the Hagarenes, attributed to a monk called Apollo. In: Hurwitz, N., Sahner, C. C., Simonsohn, U. and Yarbrough, L. (eds.) Conversion to Islam in the premodern age: a sourcebook. University of California Press, Berkeley, pp. 167-171. ISBN 9780520296732 Available at http://centaur.reading.ac.uk/94531/

It is advisable to refer to the publisher's version if you intend to cite from the work. See Guidance on citing.

Publisher: University of California Press

All outputs in CentAUR are protected by Intellectual Property Rights law, including copyright law. Copyright and IPR is retained by the creators or other 
copyright holders. Terms and conditions for use of this material are defined in the End User Agreement.

\section{www.reading.ac.uk/centaur}

\section{CentAUR}

Central Archive at the University of Reading

Reading's research outputs online 
Frontmatter:

A monk deploring the assimilation of the Christians to the Hagarenes.

- Anonymous work attributed to Samuel of Qalamūn.

- The Apocalypse of Samuel of Qalamūn.

- Apocalypse

- Text in Jean Ziadeh, "L'Apocalypse de Samuel, supérieur de Deir-el-Qalamoun," Revue de l'Orient Chrétien 20 (1915-1917): 374-404 (edition and French translation based on Paris.

Ar. 150); a list of 22 manuscripts containing the text and some textual amendments in Khalil Samir, "L'Apocalypse de Samuel de Qalamūn et la domination des Hagaréens," in "Guerra santa » e conquiste islamiche nel Mediterraneo (VII-XI secolo), ed. Marco Di Branco and Kordula Wolf (Rome: Viella, 2014), 17-63.

Introduction:

This is an extract from a longer text probably dating to the late tenth or early eleventh century, but with a frame narrative that places it in the late seventh century. The purported author, the monk Apollo, claims it is a prophecy he heard from the mouth of Samuel, his spiritual master and the founder and superior the monastic community of Qalamunn in the Fayyūm (Egypt), in the presence of all the brothers and of Gregory, bishop of al-Qais. The text is clearly a product of the Qalamūn community, and shows knowledge of the Coptic Life of Samuel, an account of the foundation of the monastery written shortly after the Arab conquest. The contents of the text place it much later, at a time of transition for the Christians of Egypt, when linguistic and cultural assimilation to the ruling Muslims is becoming threatening to the eyes of the monks of Qalamūn. Indeed, the main aim of the Apocalypse is to describe this assimilation and to warn Christians against it, by listing the punishments for those who indulge in it and promoting the benefits of keeping to their own traditions. The new people (umma) will initially be friendly to the Christians, we are told, but they will soon start oppressing them financially and religiously. Eventually God will help the righteous regain their freedom through the intervention of the kings of Rüm (Byzantium) and Abyssinia. The largest part of the text laments the Christian imitation of the ways of the Arabs, which entails the loss of ancestral traditions. The author focuses unusually strongly on linguistic assimilation, which for him involves a loss of communal memory and ritual efficiency: Christians no longer understand the books with their own history, nor what is said during the holy rites. He castigates the clergy for not withstanding this development but going along with it. Even though he does not talk about conversion as such, he understands this assimilation as a first step towards it, since it is not only a form of forgetting the teachings of the Gospel and the Fathers, but the abandonment a holy language with a Christian essence (Coptic) in favour of a Muslim one (Arabic).

Text:

[379] (fol. 22r) Woe upon woe!! What shall I say, my children, about those times and about the great idleness that will overtake the Christians? At that time they will move away from uprightness and start to assimilate themselves to the Hagarenes (yatashabbahü bi-I-hajara) ${ }^{1}$ in their actions: they will give their names to their children, discarding the names of the

\footnotetext{
${ }^{1}$ I have vocalised the Arabic هجرة as hajara, following Iskander (1998) and especially Samir (2014), who argued at some length in favour of this reading. Previous translations have vocalised it as hijra and translated as 'hegira' or 'emigrants'.
} 
angels, the prophets, the apostles and the martyrs.

They will also do something else, that if I were to tell you of it your hearts would be greatly pained: they will abandon (yatrukū) the beautiful Coptic language, in which the Holy Spirit has often spoken through the mouths of our spiritual fathers; they will teach their children from an early age to speak the language of the Bedouin ( $a l-a^{\prime} r a \bar{b} b$ ), and will take pride in it. Even the priests and monks will-they too!-dare to speak in Arabic and to take pride in it, and that within the sanctuary (al-haykal).

Woe upon woe!! Oh my dear children! What shall I say? At that time the readers in the church will no longer understand what they read nor what they say because they will have forgotten their language (nasu lughatahum), and they will truly be miserable and deserving to be wept over because they will have forgotten their language and will speak the language of the Hagarenes.

But woe to every Christian who teaches his son the language of the Hagarenes from an early age, causing him to forget the language of his fathers! He will be responsible for his transgression, as it is written, 'Parents will be judged for their sons'.

What shall I say on account of the moral slackness that is overtaking the Christians: they eat and they drink inside the sanctuary without fear. They have forgotten the fear of the sanctuary, and the sanctuary is nothing to them. The doors of the sanctuary will be forlorn, and no half-deacon (fol. 22v) will remain at them, because they will neglect the seven rites (i.e. sacraments) that the Church has and they will not fulfill them. You will see the men of those times look for clerical rank [380] while they are not yet ready to be readers and to read before the people.

Many books of the Church shall fall into disuse (tabțulu), because there shall be nobody among them to take care of the books, their hearts being attracted by the Arabic books. ${ }^{2}$ They will forget many martyrs at that time because their biographies will fall into disuse and there will be none left. The few biographies that will be found, if they are read, many people will not understand what is read because they will not know the language. And many churches, at that time, will fall into ruin, and they shall be deserted during the eves of the feasts and on the eve of Sunday too. There will be no one among them who will read a book on a pulpit, not even during the forty holy ones (i.e. Lent) that are intended for our salvation. You will find no one to read to the people, or to preach to them, because they will have forgotten the language and not understand what is read to them, or have any knowledge of it. So too, the readers shall not understand, even in Arsinoe, the great city which is in the Fayyūm, and all of its districts, where the lovely laws of Christ are in their books.

Those that are strong in the knowledge of God, whose Coptic language equalled in their mouths the sweetness of honey and spread around them like the smell of perfumes because of their beautiful pronunciation of the Coptic language, and all of them, at that time, shall all abandon it and speak the Arabic language and take pride in it, to the point that it will be impossible to recognize them as Christians; on the contrary, they will be taken for barbarians. ${ }^{3}$ And the remnant remaining in the South (wa-l-baqiyya allati tabqā fi l-Sa'îd)

\footnotetext{
${ }^{2}$ According to Jos van Lent, who is preparing a critical edition of the text, the other extant manuscripts indicate the reading al-ghariba of Paris. Ar. 150 is a misreading in Arabic for al-a rabiya. The same is true further in the text with the expression 'Arabic names' (the manuscript used by Ziadeh has al-gharïba).

${ }^{3}$ The text has barbar; this has been often translated as 'Berbers' (including by Ziadeh), who are commonly mentioned as raiders in texts from the Fayyūm. The context of opposing two languages, one civilised and one not, as well as the author's tendency to call the Muslims al-a $a \overline{r a} b$ (rather than al'arab), implying they are uncivilised Bedouin, makes the meaning 'barbarians' a more plausible option. Besides, the term Berbers is itself derived from ßó $\rho \beta \alpha \rho \circ$, which is what the Life of Samuel calls them.
} 
who will know the Coptic language and speak in it will be reviled and mocked (fol. 23r) by their brothers the Christians who speak in the Arabic language.

Woe upon woe!! How great the sorrow and how afflicting the acts that will be accomplished by the Christians at that time! Truly my heart was in great pain as I brought you those tidings, my eyes shed tears and my body was greatly shaken. Do you think there is for the heart a greater pain than to see the Christians abandon their sweet language (yatrukū lughatahum al-hilwa) to take pride in the Arabic language and in their names? In truth I tell you, my children, that those who will abandon the names of the saints (asmā'a Iqiddisin) [381] to give their children Arabic names, those who will act thus will be excluded from the blessing of the saints; and whoever will dare to speak, within the sanctuary, in the language of the Hagarenes, he will have diverged from the instructions of our holy Fathers.

[384] (fol. 25r) ... And now I recommend to you, my dear children, I beseech you humbly to recommend to those who will come after you till the end of times, to watch over their souls perfectly and not to let a Christian speak Arabic in this place, because it will bring about an ominous judgement. Many at that time will indeed dare to speak the language of the Hagarenes at the altar (al-madhbah). Woe upon woe on them!! As I have myself heard from an old man devoted to the service of God, clothed with the Spirit and accomplished in holiness, when I asked him concerning the Hagarenes, he answered, 'Look, my son Samuel, and understand what I tell you. At the time when (fol. 25v) the Christians shall dare to speak near the altar in the language of the Hagarenes, through which they will blaspheme against the Holy Spirit and against the Holy Trinity, at that time woe to the Christians! Woe, sevenfold woe!'

\section{(...)}

[388] (fol. 28r) Instruct (awwașū) your children, who will instruct (yawwașū) those who come after them unto the end of the future times, that no one should speak at the altar the language of the Hagarenes. For he who acts in this way will deserve a curse (la nah).

\section{Further reading:}

- John Iskander, "Islamization in medieval Egypt. The Copto-Arabic 'Apocalypse of Samuel' as a source for the social and religious history of medieval Copts," Medieval Encounters 4 (1998): 219-227; Arietta Papaconstantinou, "'They shall speak the Arabic language and take pride in it': reconsidering the fate of Coptic after the Arab conquest," Le Muséon 120 (2007): 273-299; Jason R. Zaborowski, “Egyptian Christians implicating Chalcedonians in the Arab takeover of Egypt: the Arabic Apocalypse of Samuel of Qalamūn," Oriens Christianus 87 (2003): 100-115; id., "From Coptic to Arabic in medieval Egypt," Medieval Encounters 14 (2008): 15-40. 